\title{
Analisis Keuntungan Dan Analisis Keuntungan Dan Strategi Pengembangan Usaha Ayam Buras Unggul Varietas Jowo Super (JOPER) Di Kabupaten Jember
}

\author{
Eko Andris Widayanto ${ }^{1}$, Syamsul Hadi ${ }^{2}$, Saptya Prawitasari ${ }^{3}$ \\ Universitas Muhammadiyah Jember ${ }^{1,2,3}$
}

\begin{abstract}
This study aims to determine the profitability of domestic chicken business in Jember Regency, to find out the factors that influence the profitability of chicken farming in Jember Regency, determine the development strategy domestic chicken in Jember Regency. This researche used survey method. The research was conducted in 3 (three) Subdistricts namely Bangsalsari, Umbulsari, and Gumukmas Subdistricts, in Jember Regency. The data used in this researche include primary data and secondary data. The data is done qualitatively and quantitatively. The analysis used is profit analysis, multiple regression analysis and SWOT analysis. This researche concludes that (1) Wild Chicken Jowo Super (Joper) Business in Jember Regency is profitable with an average revenue gain of Rp. 9,749,038 per production process, and the total production costs are Rp. 9,082,346 per production process. The average business profit rate of Buras Joper Chicken in Kabupaten Jember is IDR 666,693 / production process / 404 heads. (2) Business Benefits of Burst Joper Chicken are influenced by 5 independent variables namely price $\left(X_{1}\right)$, production $\left(X_{2}\right)$, cost of production facilities $\left(X_{3}\right)$, labor costs $\left(X_{4}\right)$, and other costs $\left(X_{5}\right)$ with a positive relationship and significant at the real level of five percent. This is indicated by the results of the calculated $F$ test greater than $F$ table at the real level of 99\%. Simultaneously the factors have a significant effect on profits including price, production, production facilities, labor costs and other costs. But partially significant factors include the price of output and production, while the ones that are not significant include the costs of means of production, labor costs, and other costs. (3) Based on the results of the SWOT Analysis, the Buras Chicken Business in Jember Regency is in position / quadrant I (Growth / Aggressive / progressive). This position signifies a strong and potential business, meaning that the business is carried out in prime condition. So that it is truly possible to continue to expand, increase growth and achieve maximum progress.
\end{abstract}

Keywords: joper fried chicken, profit, SWOT

\section{Pendahuluan}

Ayam buras merupakan komoditas yang potensial untuk dikembangkan dengan menggunakan sumberdaya lokal. Penyebaran ayam buras yang meluas disebabkan pemeliharaannya relatif mudah karena tidak membutuhkan persyaratan yang cukup berat, dan sebagai sebagai ternak lokal ayam buras telah beradaptasi pada berbagai lingkungan (Soediroatmojo, 2007). Ayam kampung super merupakan hasil persilangan terbaru antara ayam jawa/kampung dengan ayam arab yang melibatkan teknologi persilangan ternak sehingga didapatkan pertumbuhan yang cepat dan memiliki karakteristik daging dan bentuk ayam kampung. Ayam kampung super memiliki kandungan gizi yang tinggi dan rasanya 
lezat. Ayam kampung super memiliki kandungan protein tinggi, digunakan sebagai penguat stamina tubuh, obat hati/liver, serta memperlancar persalinan dan air susu ibu. Sedangkan Ayam jawa/kampung merupakan ayam tradisional di Indonesia yang kehidupannya sudah lekat dengan manusia. Tujuan penelitian ini adalah: (1) Mengetahui tingkat keuntungan usaha ayam buras di Kabupaten Jember. (2) Mengetahui faktor-faktor yang berpengaruh terhadap keuntungan usaha ayam buras di Kabupaten Jember. (3) Menentukan straegi pengembangan ayam buras di Kabupaten Jember.

\section{Tinjauan Pustaka}

Tinjauan teoristis yang digunakan adalah, teori keuntungan, teori produksi, teori biaya, dan teori strategi. (Suardy 2013 ) dalam hasil penelitiannya mengemukakan bahwa bahwa rata-rata pendapatan peternak ayam buras pada skala usaha 1000 ekor sebesar Rp 21,914,758. Selanjutnya Rahayu (2011) dari hasil penelitiannya mengungkapkan bahwa faktor-faktor yang berpengaruh secara nyata terhadap keuntungan meliputi harga, produksi, biaya sarana produksi, biaya Tenaga kerja dan biaya lain-lain. Berikut kerangka pemikiran usaha ayam buras di Kabupaten Jember

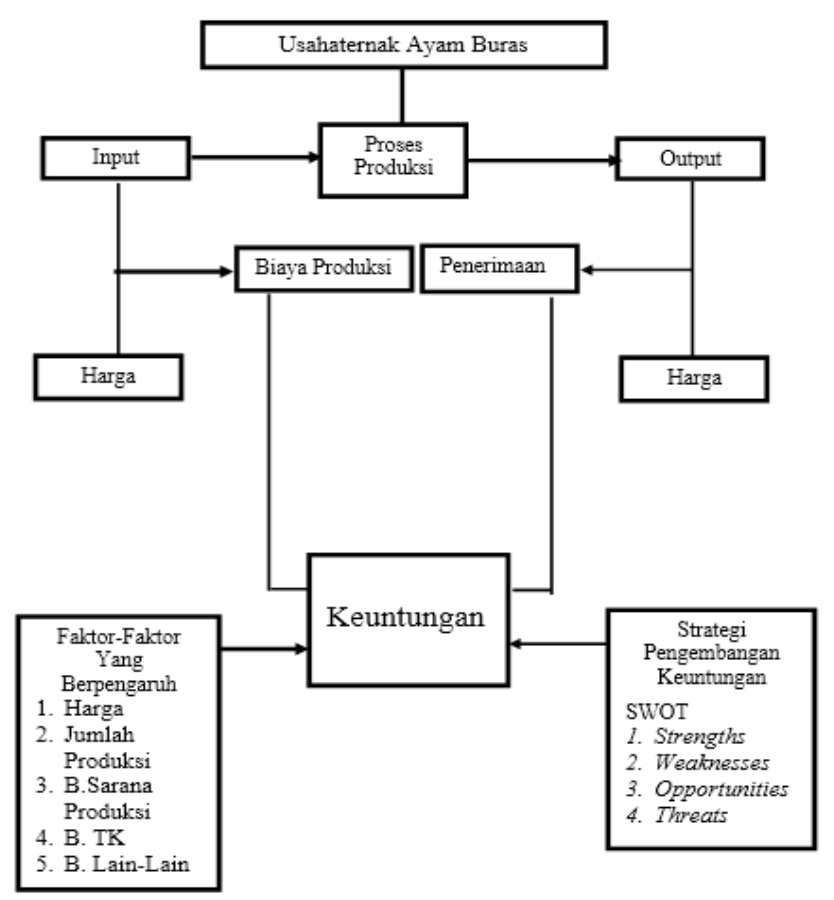

Gambar 1. Usaha Ternak Ayam Buras

Berdasarkan uraian di atas maka peneliti merumuskan hipotesis sebagai berikut:

1. Diduga faktor-faktor yang mempengaruhi tingkat keuntungan uasaha ayam buras adalah harga output, jumlah produksi dan biaya produksi. 


\section{Metode Penelitian}

Metode yang digunakan dalam penelitian ini adalah metode survei. Metode survei merupakan cara untuk mengumpulkan data dari sejumlah unit atau individu dalam jangka waktu tertentu secara langsung kepada petani atau responden (Singarimbun, 1981).

\section{Daerah Penelitian}

penelitian ini dilakukan dengan sengaja (purposive) yaitu Kecamatan Bangsalsari, Umbulsari, dan Gumukmas di Kabupaten Jember sebagai lokasi penelitian.

\section{Metode Pengambilan Sampel}

Jumlah responden yang dijadikan sampel dalam penelitian ini berjumlah 106 orang dengan pengambilan sampel 52 orang peternak ayam buras. Dan pemilihan besar sampel untuk populasi ternak ayam buras dilakukan dengan menggunakan rumus slovin dengan batas toleransi kesalahan (error tolerance) 10\% (Sevilla et. al., 1960). $\mathrm{n}=\frac{N}{1+N e^{2}}$ dimana:

$$
\begin{aligned}
& \mathrm{n}=\text { Jumlah sample } \\
& \mathrm{N}=\text { jumlah populasi } \\
& \mathrm{E}=\text { batas toleransi kesalahan (error tolerance) }
\end{aligned}
$$

\section{Metode Pengumpulan Data}

Data yang digunakan dalam penelitian ini meliputi data primer dan data sekunder. Data primer merupakan data yang diperoleh secara langsung dari peternak responden dengan melakukan wawancara yang berpedoman pada daftar pertanyaan yang telah disusun sebelumnya, data ini berkaitan dengan tenaga kerja, produksi, harga, dan biaya. Sementara itu, data sekunder merupakan data yang diperoleh dari dinas atau instansi yang berhubungan dengan penelitian ini, antara lain adalah Badan Pusat Statistik, Dinas Peternakan, Kabupaten Jember.

\section{Metode Analisis Data.}

Dalam penelitian ini, metode analisis data yang akan digunakan untuk menguji hipotesis pertama mengenai ada perbedaan tingkat keuntungan antara peternak. Sementara itu, untuk mengukur besarnya keuntungan peternak ayam buras digunakan pendekatan analisis keuntungan dengan formulasi sebagai berikut (soekartawi,1990):

dimana:

$$
\begin{array}{ll}
\pi & =\mathrm{TR}-\mathrm{TC} \\
\mathrm{TR} & =\mathrm{P} . \mathrm{Q} \\
\mathrm{TC} & =\mathrm{TFC}+\mathrm{TVC} \\
\pi & =\mathrm{P} . \mathrm{Q}-(\mathrm{TFC}+\mathrm{TVC})
\end{array}
$$

$\pi \quad=$ Keuntungan $(\mathrm{Rp})$ 


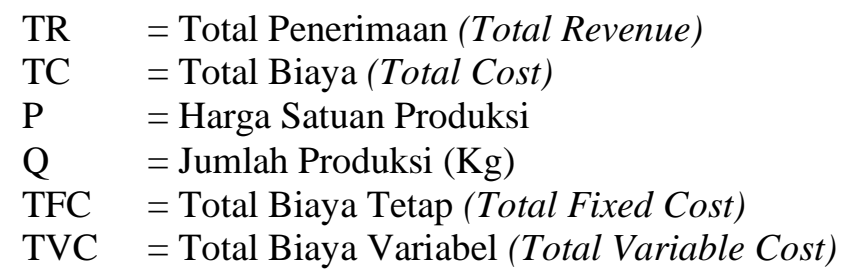

2. Untuk menguji hipotesis kedua mengenai faktor yang berpengaruh terhadap keuntungan digunakan pendekatan analisis regresi berganda, dengan asumsi bahwa bentuk hubungan antara variable (X) dengan variable (Y) merupakan fungsi produksi Cobb-Douglas. Hubungan antara variable $\mathrm{X}$ dan $\mathrm{Y}$ tersebut, secara matematika dirumuska sebagai berikut (Sutiarso, 2010).

$$
Y_{i}=\beta_{0} X_{1}^{\beta_{1}} X_{2}^{\beta_{2}} \cdots X_{k_{i}}^{\beta_{k}} \ell^{u_{i}}
$$

Faktor-faktor yang diduga berpengaruh terhadap keuntungan adalah harga, output, jumlah produksi dan biaya produksi. Secara matenatis, persamaan taksiran fungsi keuntungan dengan model regresi adalah:

$$
\hat{Y}=b_{0} X_{1}^{b_{1}} X_{2}^{b_{2}} X_{3}^{b_{3}} X_{4}^{b_{4}} X_{5}^{b_{5}}
$$

di mana:

$\hat{Y}=$ Keuntungan usaha peternakan ayam buras

$\mathrm{X}_{1}=$ Harga Output $(\mathrm{Rp})$

$\mathrm{X}_{2}=$ Produksi $(\mathrm{Kg})$

$\mathrm{X}_{3}=$ Biaya Sarana Produksi $(\mathrm{Rp})$

$\mathrm{X}_{4}=$ Biaya Tenaga Kerja $(\mathrm{Rp})$

$\mathrm{X}_{5}=$ Biaya Lain-lain $(\mathrm{Rp})$

$\mathrm{b}_{0}=$ Konstanta

$\mathrm{b}=$ Koefisisen Regresi Variabel Bebas

Untuk memudahkan pendugaan persamaan tersebut di atas, maka persamaan tersebut diubah menjadi bentuk lenier berganda dengan cara melogaritmakan. Persamaan regresi dinyatakan dalam bentuk persmaan logaritma dengan bilangan pokok e $=$ 2.71828183, sehingga persmaannya menjadi:

dimana:

$$
\operatorname{In} Y_{i}=\operatorname{In} \beta_{0}+\beta_{1} \operatorname{In} X_{1 i}+\ldots+\beta_{k} \operatorname{In} X_{k i}+u_{i} \text { In e }
$$

$\mathrm{Y}=$ Variabel Terikat (Dependen Variabel)

$\mathrm{X}=$ Variabel Bebas (Independen Variabel)

$\alpha, \beta_{1}, \ldots, \beta_{k}=$ Koefisien Regresi

$\mathrm{I}=1,2, \ldots, \mathrm{N}=$ Nomor Observasi

$\mathrm{J}=1,2, \ldots, \mathrm{K}=$ Nomor Varibel

Estimasi terhahadap bentuk hubungan di atas adalah:

$$
\operatorname{In} \widehat{Y}=\operatorname{In} a+b_{i} \operatorname{In} X_{i}+\cdots+b_{i} \operatorname{In} X_{j}+\ldots+b_{k} \operatorname{In} X_{i}
$$


dimana:

$\hat{Y}=$ Estimator Dari $Y$

$\mathrm{a}=$ Estimator Dari $\alpha$

$\mathrm{b}_{1}, \mathrm{~b}_{2}, \ldots \mathrm{b}_{\mathrm{k}}$ Masing masing estimator dari $\beta_{1}, \beta_{2}, \ldots, \beta_{\mathrm{k}}$

$\mathrm{u}=$ In $\mathrm{Y}-\mathrm{In} \hat{Y}=$ Estimator kesalahan pengganggu $(\mathrm{u})$

Pengujian terhadap hipotesis yang diajukan dalam analisis untuk kepentingan estimasi dan inpresentasinya meliputi:

1. Penguji keberartian koefisien regresi pasrsial secara keseluruhan (simultan)

$H_{0}$ : semua koefisien regresi dari factor-faktor yang berpengaruh terhadap keuntungan

tidk berbeda nyata dengan nol.

$$
\beta_{1} \beta_{2}=, \ldots,=\beta_{\mathrm{k}}=0
$$

$\mathrm{Ha}=$ paling tidak salah satu koefisien regresi dari faktor-fakor yang berpengaruh terhadap keuntungan berbeda nyata dengan nol, atau $\beta_{\mathrm{j}} \neq 0$

Pengujian hipotesis dilakukan secara statistic menggunakan uji F dengan formulasi sebagai berikut:

$$
\begin{aligned}
& F_{\text {hitung }}=\frac{\text { kuadran tengah regresi }}{\text { kuadran tengah sisa }} \\
& \text { jika }\left|F_{\text {hit }}\right|\left|\begin{array}{l}
\leq F_{(\propto: n-k-1), \text { maka } H_{0} \text { diterima }} \\
>F_{(\propto: n-k-1), \text { maka } H_{0} \text { ditolak }}
\end{array}\right|
\end{aligned}
$$

dimana:

$\mathrm{n}=$ Jumlah Observasi

$\mathrm{k}=$ Jumlah Variable Bebas

2. Pengujian keberartian koefesien regresi secara parsial

Untuk faktor yang berpengaruh positif terhadap keuntungan yang diajukan

hipotesis statistic sebagai berikut:

$H_{0}$ : Koefisien regresi dari faktor produksi yang berpengaruh positif terhadap keuntungan tidak berbeda atau sama dengan nol, atau $\beta_{j} \leq 0$

$H \mathrm{a}$ : Koefisien regresi dari faktor produksi yang berpengaruh positif terhadap keuntungan tidak sama dengan nol, atau $\beta_{j}>0$

Untuk faktor yang berpengaruh negative terhadap keuntungan yang diajaukan hipotesis statistik sebagai berikut:

$H_{0}$ : Koefisien regresi dari faktor produksi yang berpengaruh negatif terhadapkeuntungan tidak berbeda atau sama dengan nol, atau $\beta_{j} \geq 0$

$\mathrm{Ha}$ : koefisien regresi daari faktor produksi yang berpengaruh negative terhadap 
keuntungan tidak sama dengan nol, atau $\beta_{j}<0$

Pengujian hipotesis dilakukan secara statistic dengan uji-t sebagai berikut:

dimana:

$$
t_{\text {hitung }}=\frac{b_{j}-\beta_{j}^{*}}{S_{b_{j}}}
$$

$\beta_{j}^{*}$ adalah $\beta_{j}$ yang sesuai dengan hipotesis nol,

$S_{b_{j}}$ adalah standar erir dari $b_{j}$

Kriteria Pengambilan Keputusan :

$$
\text { jika }\left|t_{\text {hit }}\right|\left|\begin{array}{l}
\leq t_{(\alpha: n-k-1), \text { maka } H_{0} \text { diterima }} \\
>t_{(\propto: n-k-1), \text { maka } H_{0} \text { ditolak }}
\end{array}\right|
$$

\section{Hasil Dan Pembahasan}

Tabel 1. Profil Peternak Usaha Ayam Buras Di Kabupaten Jember Tahun 2018

\begin{tabular}{clc}
\hline No. & \multicolumn{1}{c}{ Keterangan } & Rata-Rata/Responden \\
\hline 1 & Umur (th) & 44 \\
2 & Pendidikan (th) & 12 \\
3 & Jml. Anggota Kel. (Jiwa) & 3 \\
4 & Jml. Ternak ayam buras. (Ekor) & 404 \\
\hline
\end{tabular}

Sumber: Analisis data primer (2018).

Menunjukkan bahwa rata-rata umur peternak di Kabupaten Jember adalah 44 tahun. Umur pengusaha ayam buras termasuk dalam kategori umur yang produktif, umur menunjukkan kematangan rasa berfikir seseorang dalam melaksanakan suatu kegiatan usaha dan mengatasi problema yang dihadapi, ditinjau dari segi kematangan dan cara pengambilan keputusan yang perlu diambil pada pelaksanaan usahatani, maka pengusaha ayam buras yang berusia produktif akan lebih cermat dan akurat.

Tabel 2. Rata-Rata Biaya Usaha Ayam Buras Jowo Super (Joper) Per Unit Usaha Di Kabupaten Jember Tahun 2018

\begin{tabular}{cllrrrr}
\hline No & \multicolumn{1}{c}{ Uraian } & Satuan & Volume & Harga/Unit & Nilai (Rp) & \% \\
\hline $\mathbf{1}$ & Biaya Tetap & & & & & \\
& A. Sewa Lahan & M $^{2}$ & 23 & 50 & 1.130 & 0,01 \\
& B. Listrik & Ls & 1 & 47.423 & 47.423 & 0,52 \\
& C. Sekam & Karung & 8 & $7.204,28$ & 58.327 & 0,64 \\
& D. Penyusutan & Ls & 1 & 145.524 & 145.524 & 1,60 \\
& Jumlah Biaya & & & & $\mathbf{2 5 2 . 4 0 4}$ & $\mathbf{2 , 7 7}$ \\
& Tetap & & & & \\
$\mathbf{2}$ & Biaya Variabel & & & & & \\
& A. Bibit & Ekor & 404 & 5.903 & 2.384 .038 & 26,24
\end{tabular}




\begin{tabular}{llrrrr} 
B. Pakan & Karung & 12 & 344.953 & 4.252 .212 & 46,81 \\
C. Obat-Obatan & Pcs/Botol & 13 & 12495,56 & 162.442 & 1,78 \\
D. TK & HKP & 51 & 39.722 & 2.031 .250 & 22,36 \\
Jumlah Biaya & & & & $\mathbf{8 . 8 2 9 . 9 4 2}$ & $\mathbf{9 7 , 2 2}$ \\
\hline Variabel & & & & & $\mathbf{9 . 0 8 2 . 3 4 6}$ \\
\hline Total Biaya & & $\mathbf{5 1 1}$ & $\mathbf{4 1 0 . 3 3 1}$ & $\mathbf{1 0 0}$ \\
\hline
\end{tabular}

Sumber: Analisis data primer (2018).

Berdasarkan Tabel 6.2 menunjukkan bahwa jumlah total biaya produksi usaha ayam buras di Kabupaten Jember yaitu sebesar Rp 9.082.346 (RP22.482.277/1.000 ekor atau $\mathrm{Rp} 22.481 /$ ekor) yang terdiri dari biaya tetap sebesar Rp 252.404 (RP 624.762/1.000 ekor atau Rp 624/ekor) dan biaya variabel sebesar Rp 8.829.942 (RP 21.856.292/1.000 ekor atau Rp 21.856/ekor) per proses produksi. Dalam usaha ternak ayam joper beberapa input yang dipergunakan adalah bibit, pakan, obat-obatan dan biaya tenaga kerja, biaya variabel tertinggi adalah biaya pakan yaitu sebesar Rp 4.252.212 (RP 10.525.277/1.000 ekor atau Rp10.525/ekor).

Berdasarkan hasil penelitian menunjukkan bahwa rata-rata jumlah pakan per ekor sebesar 1,458 gram, jika dibandinkan dengan berat pakan pada tabel 5.5 menunjukan berat pakan sebesar 5,142 gram/ekor.

Tabel 3. Rata-Rata Produksi, Biaya, Keuntungan Per Unit Usaha Ayam Buras (Joper) Di Kabupaten Jember Tahun 2018

\begin{tabular}{rlr}
\hline No & Uraian & Nilai \\
\hline 1 & Produksi (Ekor) & 404 \\
2 & Harga (Rp) & 24.442 \\
3 & Penerimaan (Rp) & 9.749 .038 \\
4 & Biaya (Rp) & 9.082 .346 \\
\hline & Keuntungan (Rp) & $\mathbf{6 6 6 . 6 9 3}$ \\
\hline
\end{tabular}

Sumber: Data Primer diolah (2018).

Tabel 6.3. menunjukkan bahwa rata-rata total produksi pada usaha ayam buras adalah sebesar 404 ekor dengan rata-rata harga ayam joper harga sebesar Rp.24.442 /ekor. Sementara itu, jumlah produksi dan harga mempengaruhi rata-rata total penerimaan per proses produksi ayam buras di Kabupaten Jember, penerimaan di dapat dari harga dikali produksi, penerimaan yang diperoleh per proses produksi yaitu sebesar Rp 9.749.038.

Hasil dari Tabel 6.3 menunjukkan bahwa keuntungan yang diperoleh peternak yaitu sebesar Rp 666.693 /proses produksi/ 404 ekor, atau sebanyak Rp.164.852 /proses produksi 100 ekor, secara ekonomis menguntungkan, hal ini dikarenakan rata-rata biaya yang dikeluarkan selama produksi sebesar Rp.9.082.346 per proses produksi, lebih kecil dari rata-rata penerimaan yang diperoleh peternak yaitu sebesar Rp 9.749 .038 per proses 
produksi. Keuntungan yang diterima oleh peternak usaha ayam buras yaitu sebesar $\mathrm{Rp}$ 666.693, hal ini dikarenakan tingginya biaya variabel yaitu biaya tenaga kerja sebesar $\mathrm{Rp}$ 2.031.250 sehingga keuntungan yang diperoleh peternak sangat kecil atau kurang dari 1juta.

Tabel 4. Hasil Analisis Regresi Berganda Faktor-Faktor Keuntungan Usaha Ayam Buras Di Kabupaten Jember Tahun 2018

\begin{tabular}{lcccc}
\hline \multicolumn{1}{c}{ Variabel } & $\begin{array}{c}\text { Koefisien } \\
\text { Dugaan }\end{array}$ & St-Eror & t-hitung & Sig \\
\hline Konstanta & 3.571 & 15.235 & 0,234 & .816 \\
Harga Output $\left(\mathrm{X}_{1}\right)$ & 8.938 & 1.572 & $5.686^{* * *}$ & 0,000 \\
Produksi $\left(\mathrm{X}_{2}\right)$ & 9.606 & 0,826 & $11.634^{* * *}$ & 0,000 \\
Biaya Sarana Produksi $\left(\mathrm{X}_{3}\right)$ & -5.757 & 0,655 & $-8.795^{* * *}$ & 0,000 \\
Biaya Tenaga Kerja $\left(\mathrm{X}_{4}\right)$ & -2.795 & 0,308 & $-9.085^{* * *}$ & 0,000 \\
Biaya Lain-Lain $\left(\mathrm{X}_{5}\right)$ & $-0,549$ & 0,292 & $-1.880^{\mathrm{ns}}$ & 0,66 \\
\hline $\mathrm{R}^{2}$ & 0,780 & & & \\
$\mathrm{R}-$ Sq (Ad j) & 0,756 & & & \\
F-tabel & 2,42 & & & \\
t-tabel & 2,006647 & & & \\
\hline Kabel & & & &
\end{tabular}

Keterangan $(* * *)=$ Signifikan Pada a $99 \%$, Ns $=$ Non Signifikan

Sumber: Data Primer Diolah

Koefisien derminasi $\left(\mathrm{R}^{2}\right)$ yang dihasilkan dari keuntungan usaha ayam buras di Kabupaten Jember bernilai 75,6\%. Hal ini menunjukkan 75,6\% keuntungan dapat dijelaskan oleh variabel-variabel keuntungan yang digunakan. Uji F yang diperoleh dari model tersebut sebesar 32,658 jauh lebih besar dari pada F tabel yaitu 2,42. Hal tersebut menunjukkan bahwa statistik model dapat berpengaruh nyata pada taraf kepercayaan $99 \%$. Artinya bahwa faktor-faktor keuntungan usaha ayam buras berupa harga output, produksi, biaya sarana produksi, biaya tenaga kerja, dan biaya lain- secara bersama-sama mempengaruhi keuntungan usaha ayam buras yang dihasilkan.

Pengaruh faktor-faktor keuntungan secara parsial untuk model ini dapat diuji dengan uji-t. Apabila nilai t hitung lebih besar dari nilai t tabel yaitu 2,006647 maka faktorfaktor keuntungan berpengaruh nyata terhadap perubah tidak bebas atau output. Dapat disimpulkan bahwa variable harga, produksi, biaya sarana produksi, biaya tenaga kerja, dan biaya lain-lain berpengaruh nyata terhadap keuntungan usaha ayam buras.

Hasil pendugaan fungsi keuntungan usaha ayam buras di Kabupaten Jember sebagai berikut :

$\operatorname{Ln} Y=\operatorname{Ln} 3,571+8,938 \operatorname{Ln} X_{1}+9,606 \operatorname{Ln} X_{2}-5,757 \operatorname{Ln} X_{3}-2,795 \operatorname{Ln} X_{4}-0,549 \operatorname{Ln} X_{5}$

Atau dapat diubah dalam fungsi sebagai berikut:

$\mathrm{Y}=35,552 \mathrm{X}_{1}{ }^{8,938} \mathrm{X}_{2}{ }^{9,606} \mathrm{X}_{3}{ }^{-5,575} \mathrm{X}_{4}{ }^{-2,795} \mathrm{X}_{5}^{-0,549}$ 
Nilai elastisitas pada setiap variabel sebesar 7,014 yang berarti bahwa keuntungan usaha ayam buras berada pada skala kenaikan hasil yang semakin meningkat (increasing return to scale). Nilai elastisitas yang lebih dari satu ini berarti bahwa penambahan faktor keuntungan sebesar satu persen dalam keuntungan menyebabkan kenaikan hasil ayam buras sebesar 7,014 persen.

Berdasarkan hasil analisis regresi berganda pada faktor-faktor keuntungan usaha ayam buras mempunyai nilai koefisien dan Variance Inflation Factor (VIF) yang berbeda-beda. Nilai VIF memberikan identifikasi bahwa antar variabel mempunyai multikolinearitas didalam model, yaitu dimana keadaan antar variabel prediktor terdapat hubungan yang sangat erat. Apabila nilai VIF lebih dari 10, maka taksiran parameter kurang baik. (Mustofa, 2008)

\section{Kesimpulan}

Berdasarkan perumusan masalah, tujuan penelitian, hipotesis, dan hasil penelitian serta pembahasan, maka dapat disimpulkan bahwa:

1. Usaha ayam buras varietas jowo super (Joper) di Kabupaten Jember menguntungkan dengan penerimaan sebesar Rp 9.749.038 per proses produksi ( 2 bulan), dan total biaya produksi sebesar RP 9.082.346 per proses produksi. Rata-rata tingkat keuntungan usaha ayam buras joper di Kabupaten Jember adalah sebanyak Rp 666.693 /proses produksi/ 404 ekor, atau sebanyak Rp164.852 /proses produksi (100 ekor).

2. Keuntungan usaha ayam buras joper dipengaruhi oleh 5 variabel independen yaitu harga $\left(\mathrm{X}_{1}\right)$, produksi $\left(\mathrm{X}_{2}\right)$, biaya sarana produksi $\left(\mathrm{X}_{3}\right)$, biaya tenaga kerja $\left(\mathrm{X}_{4}\right)$, dan biaya lain-lain $\left(\mathrm{X}_{5}\right)$ dengan hubungan positif dan signifikan pada taraf nyata lima persen. Hal ini ditunjukan hasil uji $\mathrm{F}$ hitung lebih besar dari $\mathrm{F}$ tabel pada taraf nyata 1\%. Secara simultan faktor-faktor berpengaruh nyata terhadap keuntungan meliputi harga, produksi, biaya sarana produksi, biaya Tenaga kerja dan biaya lain-lain. Namun secara parsial faktor-faktor yang berpengaruh nyata meliputi harga output dan produksi, sedangkan yang berpengaruh tidak nyata meliputi biaya sarana produksi, biaya tenaga kerja, dan biaya lain-lain.

3. Berdasarkan hasil Analisis SWOT, usaha ayam buras di Kabupaten Jember berada pada posisi/kuadran I (Pertumbuhan/Agresif/progresif). Posisi ini menandakan sebuah usaha yang kuat dan berpeluang, artinya usaha yang dilakukan dalam kondisi prima. Sehingga benar-benar dimungkinkan untuk terus menjalankan ekspansi, memperbesar pertumbuhan dan meraih kemajuan secara maksimal. 
Berdasarkan permasalahan, pembahasan, dan kesimpulan yang ada, maka dapat disarankan sebagai berikut:

1. Sebaiknya peternak ayam buras lebih memperhatikan dan mengontrol penggunaan biaya produksi usaha ayam buras, agar biaya yang dikeluarkan oleh peternak ayam buras lebih efisien khususnya dalam penggunaan input pakan dan tenaga kerja. Peternak harus terus menambah pengalaman agar lebih terampil dalam usaha ayam buras sehingga produksi terus meningkat.

2. Pemerintah harus memperhatikan dan memahami kondisi peternak terutama dalam hal harga. Pemerintah diharapkan bisa memberikan harga pasar yang tinggi guna meningkatkan keuntungan yang diperoleh peternak.

3. Penelitian ini perlu dilanjutkan mengenai usaha ayam buras di wilayah lain di luar Kabupaten Jember, untuk mengetahui apakah memiliki prospek yang sama atau mungkin lebih baik dari Kabupaten Jember serta nantinya bisa memberikan nilai positif bagi dunia peternakan khususnya peternak ayam buras varietas joper di kemudian hari.

\section{DAFTAR PUSTAKA}

Mutofa,. 2008. Factor-Faktor Yang Mempengaruhi Struktur Modal Perusahaan Manufaktur Go Public Di Bursa Efek Indonesia, Surakarta. Universitas Muhammadiyah Surakarta.

Rahayu, C.D 2011. Analisis Usahatani Kedelai (Studi Kasus di Kecamatan Bangsalsari, Kabupaten Jember). Fakultas Pertanian. Universitas Muhammadiyah Jember. Jember.

Suardy, Z. 2013.Analisis Pendapatan Peternak Aym Buras Yang Di Pelira Secara Intensif Dikecamatan Awangbone Kabupaten Bone, Fakultas Sosial Ekonomi peternakan,Universitas Hasanuddin. Makasar. 